$\begin{array}{ll}\text { Volume } & : 05 \\ \text { Nomor } & : 03 \\ \text { Bulan } & : \text { September } \\ \text { Tahun } & : 2019 \\ \text { http } & : / / \text { ejurnal.pps.ung.ac.id/index.php/AKSARA/index }\end{array}$

\title{
IDENTIFIKASI POTENSI LAHAN PERTANIAN DI DESA BALATE KECAMATAN PAGUYAMAN SEBAGAI DESTINASI BERBASIS AGROWISATA
}

\author{
Lisna Bantulu \\ Universitas Negeri Gorontalo \\ Email: lisnabantulu@gmail.com
}

Received: 02 Juni 2019; Revised: 19 Juli 2019; Accepted: 25 Agustus 2019

\begin{abstract}
ABSTRAK
Dalam upaya menggali potensi agrowisata di Desa Balate untuk dijadikan sebagai destinasi berbasis agrowisata di Kabupaten Boalemo, telah dilakukan penelitian di Lahan Pertanian d masyarakat khususya petani di Desa Balate Kecamatan Paguyaman Kabupaten Boalemo. Adapun tujuan penelitian ini adalah untuk: 1) memperoleh gambaran potensi Desa Balate sebagai lokasi pembangunan agrowisata di Kabuapeten Boalemo, 2) mendeskripsikan pendapat pemerintah dan masyarakat, Penelitian ini menggunakan tipe penelitian deskriptif kualitatif. Untuk mengetahui potensi agrowisata di Desa Balate secara jelas dapat dilakukan melalui cara identifikasi potensi pariwisata atau studi kelayakan obyek wisata. Hasil penelitian menunjukkan: 1) Desa Balate memiliki potensi untuk dibangun dan dikembangkan sebagai lokasi agrowisata 2) Masyarakat mendukung pembangunan agrowisata di kawasan lahan pertanian khusus tanaman kakao. 3) Berdasarkan konsep studi kelayakan obyek wisata maka yang menjadi daya tarik utama dalam obyek wisata ini adalah wisata agro budi daya tanaman kakao, dan obyek wisata pendukung adalah wahana outbound.

Kata kunci: Identifikasi, destinasi, agrowisata
\end{abstract}

\section{PENDAHULUAN}

Provinsi Gorontalo merupakan salah satu provinsi yang memiliki potensi lahan pertanian dan tanaman pertanian yang berpotensi dalam pengembangan destinasi berbasis agrowisata. Provinsi Gorontalo memiliki luas lahan pertanian \pm 300.292 Ha yang tersebar di 5 kabupaten dan di Kota Gorontalo. Dimana luas lahan yang telah dimanfaatkan $\pm 111.746 \mathrm{Ha}$ dan yang belum dimanfaatkan \pm 115.997 Ha. Dengan 5 komoditi unggulan yakni kakao, kelapa, tebu, cengkeh, dan jagung (Data statistik Dinas Perkebunan dan Peternakan Provinsi Gorontalo Tahun 2013).

Kabupaten Boalemo merupakan salah satu kabupaten di Provinsi Gorontalo yang memiliki luas wilayah 2.248,24 km2 atau 18,4 \% luas Provinsi Gorontalo, secara administratif terdiri dari 7 kecamatan dengan 67 desa dan 11 desa pemekaran dari 4 UPT. Keberadaan lokasi transmigrasi di Kabupaten Boalemo menjadikan jumlah penduduknya terus mengalami peningkatan. Hasil pendataan terakhir jumlah penduduknya 106.790 jiwa. Mata pencaharian masyarakat di Kabupaten boalemo sebagian besar adalah dari hasil pertanian. Luas lahan pertanian di kabupaten ini \pm 65.893 Ha, dimana lahan yang telah dimanfaatkan \pm 17.226 Ha dan yang belum dimanfaatkan \pm 48.627 Ha. (Data statistik Dinas Perkebunan dan Peternakan Provinsi Gorontalo Tahun 2013). Salah satu kawasan yang menjadikan sektor pertanian sebagai mata pencaharian utama yakni kecamatan Paguyaman. Kecamatan Paguyaman memiliki luas lahan pertanian \pm 21 . $663 \mathrm{Ha}$, dimana lahan yang sudah dimanfaatkan \pm 7. 460 Ha. Di kecamatan ini masyarakat menanam 5 komoditi unggulan propinsi. Desa Balate menjadi salah satu desa yang telah berhasil mengembangkan program tani unggulan propinsi yakni tanaman kakao / coklat. Keseluruhan hasil panen tanaman pertanian tersebut di jual oleh petani dalam ruang lingkup lokal (Gorontalo) dan ada beberapa 


$$
\text { A }
$$

komoditi juga yang di ekspor ke luar Gorontalo dan di ekspor ke luar negeri seperti komoditi kakao dan jagung. Keberadaan komoditi unggulan provinsi seperti komoditi kakao menjadikan kawasan pertanian budi daya kakao mempunyai potensi untuk dikembangkan sebagai kawasan agrowisata kakao, hal ini disebabkan oleh banyaknya budi daya komoditi kakao di beberapa desa yang ada di Kecamatan Paguyaman. (Data statistik Dinas Perkebunan dan Peternakan Provinsi Gorontalo Tahun 2013).

Untuk mengetahui sejauh mana potensi yang dimiliki Desa Balate jika dijadikan sebagai destinasi agrowisata maka diperlukan suatu kegiatan identifikasi studi kelayakan obyek. Menurut Janiaton Damanik \& Helmut F Weber (2006:57) ada beberapa aspek studi kelayakan dalam perencanaan agrowisata yang dapat diterapkan dalam kegiatan identifikasi potensi di Desa Balate yakni seperti menganilisis situasi lokasi, mengidentifikasi fasilitas dan infrastruktur yang tersedia, mengidentifikasi profil wisatawan dan memilih alternatif aktivitas wisata agro yang terbaik.

\section{TINJAUAN PUSTAKA \\ Definisi Pariwisata}

Menurut Oka A. Yoeti (2009:7) yang dikutip dalam buku McIntosh pariwisata adalah aktivitas, pelayanan dan produk hasil industri pariwisata yang mampu menciptakan pengalaman perjalanan bagi wisatawan.

Undang-undang No. 10 Tahun 2009 tentang Kepariwisataan mendefinisikan wisata sebagai kegiatan perjalanan yang dilakukan seseorang atau sekelompok orang dengan mengunjungi tempat tertentu untuk tujuan rekreasi, pengembangan pribadi, atau mempelajari keunikan daya tarik wisata yang dikunjungi dalam jangka waktu sementara. Pariwisata adalah berbagai macam kegiatan wisata dan didukung berbagai fasilitas serta layanan yang disediakan oleh masyarakat, pengusaha, pemerintah dan pemerintah daerah.

Menurut Gamal Suwantoro (2004:3) Pariwisata suatu perubahan tempat tinggal sementara seseorang diluar tempat tinggalnya karena suatu alasan dan bukan untuk melakukan kegiatan yang menghasilkan upah.

Menurut Pendit (1994), pariwisata dapat dibedakan menurut motif wisatawan untuk mengunjungi suatu tempat. Jenis-jenis pariwisata tersebut adalah sebagai berikut.

a. Wisata Budaya

Wisata Budaya yaitu perjalanan yang dilakukan atas dasar keinginan untuk memperluas pandangan hidup seseorang dengan jalan mengadakan kunjungan atau peninjauan ketempat lain atau ke luar negeri, mempelajari keadaan rakyat, kebiasaan adat istiadat mereka, cara hidup mereka, budaya dan seni mereka.

b. Wisata Maritim atau Bahari

Jenis wisata ini banyak dikaitkan dengan kegiatan olah raga di air, lebih-lebih di danau, pantai, teluk, atau laut seperti memancing, berlayar, menyelam sambil melakukan pemotretan, kompetisi berselancar, balapan mendayung, melihat-lihat taman laut dengan pemandangan indah di bawah permukaan air serta berbagai rekreasi perairan yang banyak dilakukan di daerah-daerah atau negara-negara maritim.

c. Wisata Cagar Alam (Taman Konservasi)

Untuk jenis wisata ini biasanya banyak diselenggarakan oleh agen atau biro perjalanan yang mengkhususkan usaha-usaha dengan jalan mengatur wisata ke tempat atau daerah cagar alam, taman lindung, hutan daerah pegunungan dan sebagainya yang kelestariannya dilindungi oleh 


$\begin{array}{ll}\text { Volume } & : 05 \\ \text { Nomor } & : 03 \\ \text { Bulan } & : \text { September } \\ \text { Tahun } & : 2019 \\ \text { http } & : \text { //ejurnal.pps.ung.ac.id/index.php/AKSARA/index }\end{array}$

undang-undang. Wisata cagar alam ini banyak dilakukan oleh para penggemar dan pecinta alam dalam kaitannya dengan kegemaran memotret binatang atau marga satwa serta pepohonan kembang beraneka warna yang memang mendapat perlindungan dari pemerintah dan masyarakat.

d. Wisata konvensi

adalah wisata yang dekat dengan wisata jenis politik. Berbagai negara pada dewasa ini membangun wisata konvensi ini dengan menyediakan fasilitas bangunan dengan ruangan-ruangan tempat bersidang bagi para peserta suatu konfrensi, musyawarah, konvensi atau pertemuan lainnya baik yang bersifat nasional maupun internasional. Indonesia mempunyai Balai Sidang Senayan di Jakarta untuk tempat penyelenggaraan sidang-sidang pertemuan besar dengan perlengkapan modern.

\section{Konsep Identifikasi Potensi Pariwisata}

Menurut Janianton Damanik \& Helmut F. Weber (2006: 52) Studi kelayakan potensi pariwisata (feasibility study) merupakan kajian yang bersifat praktis atas berbagai keunggulan dan kelemahan sumberdaya yang tersedia, yang akan dijadikan basis penyusunan rencana proyek.

Tujuan dari studi kelayakan potensi pariwisata adalah untuk menentukan kelayakan keanekaragaman dan perluasan atraksi wisata dan infrastruktur wisata

Menurut Damanik \& Helmut F. Weber (2006:57) ada beberapa aspek studi kelayakan proyek agrowisata antara lain:

1. Menganalisis situasi lokasi wisata

Fokus pertama adalah menganalisis potensi dan atraksi wisata yang ada di lokasi yang akan dijadikan tempat wisata. Dalam hal ini perlu diperhatikan keberadaan sumberdaya alam pertanian seperti tanaman pertanian pangan, kebun dan holtikultura. Potensi yang ada harus teridentifikasi secara jelas untuk menentukan kelayakan kawasan agrowisata.

2. Mengidentifikasi fasilitas dan infrastruktur yang tersedia

Fasilitas dan infrastruktur yang perlu diidentifikasi secara jelas untuk menunjang kegiatan pariwisata seperti akomodasi, restoran, souvenir shop, air bersih, moda transportasi, telepon umum, dll.

3. Mengidentifikasi profil wisatawan

Dalam identifkasi profil wisatawan, perlu diperhatikan bahwa tidak semua wisawatawan menyukai wisata agro, sehingga perlu diidentifikasi siapa yang akan diharapkan dapat datang di destinasi agrowisata.

4. Daya dukung lahan

Jumlah wisatawan yang dapat ditampung dalam lahan agrowisata dapat mempengaruhi proses pembuahan suatu tanaman pertanian. Sehingga perlu diidentifikasi secara jelas akan kapasitas lahan agro yang dapat member kepuasan kepada wisatawan.

5. Memilih alternatif aktivitas wisata yang terbaik

Kegiatan atau aktivitas wisata yang akan dikembangkan perlu identifikasi dan diseleksi secara baik. Perlu adanya aktivitas wisata yang potensial untuk dikembangkan. Selanjutnya dipilih aktivitas penunjang yang prospektif dan menguntungkan.

Berdasarkan definisi para ahli diatas maka dapat disimpulkan bahwa konsep identifikasi potensi pariwisata adalah suatu kegiatan yang bersifat kajian untuk mengidentifikasi keunggulan dan kelemahan dalam suatu proyek pariwisata. 


$\begin{array}{ll}\text { Volume } & : 05 \\ \text { Nomor } & : 03 \\ \text { Bulan } & : \text { September } \\ \text { Tahun } & : 2019 \\ \text { http } & : \text { //ejurnal.pps.ung.ac.id/index.php/AKSARA/index }\end{array}$

\section{Definisi Agrowisata}

Sutjipta (2001) mendefinisikan, agrowisata adalah sebuah sistem kegiatan yang terpadu dan terkoordinasi untuk pengembangan pariwisata sekaligus pertanian, dalam kaitannya dengan pelestarian lingkungan, peningkatan kesajahteraan masyarakat petani.

Beeton (2006) dalam Aref dan Gill (2009) menyatakan bahwa agrowisata (agrotourism) merupakan salah satu istilah yang digunakan untuk mendeskripsikan wisata di pedesaan (rural tourism), selain farm tourism, soft tourism dan ecotourism. Hal ini mengacu pada definisi yang diberikan dalam Knowd (2001) tentang rural tourism yang memposisikan pertanian dan lahannya sebagai fondasi atau dasar semua daya tarik yang dibangun di atasnya. Pemerintah melalui Surat Keputusan Bersama Menparpostel dan Menteri Pertanian No. KM.47/PW.004/MPPT/89 dan No. 204/KPTS/HK050/4/1989, mendefinisikan "Agrowisata adalah suatu kegiatan pariwisata yang memanfaatkan usaha agro sebagai obyek wisata untuk memperluas pengetahuan, pengalaman rekreasi dan hubungan usaha dibidang agro".

\section{METODE PENELITIAN}

Adapun tempat yang menjadi obyek penelitian ini adalah Lahan Pertanian budi daya tanaman kakao / coklat di Desa Balate Kecamatan Paguyaman, Kabupaten Boalemo dan Dinas Pertanian dan Perkebunan Kabupaten Boalemo dan Dinas Pariwisata Boalemo.

Penelitian ini menggunakan tipe penelitian deskriptif kualitatif. Penelitian kualitatif adalah penelitian tentang riset yang bersifat deskriptif dan cenderung menggunakan analisis dengan pendekatan induktif. Landasan teori dimanfaatkan sebagai pemandu agar fokus penelitian sesuai dengan fakta dilapangan.

Dalam penelitian kualitatif, pengumpulan data dilakukan pada natural setting (kondisi yang alamiah), sumber data primer, dan teknik pengumpulan data lebih banyak pada observasi berperan serta (participant observation), wawancara mendalam (in depth interview) dan dokumentasi.

Susan Stainback (1988) mengemukakan bahwa analisis data merupakan hal yang kritis dalam proses penelitian kualitatif. Analisis Data dalam penelitian kualitatif dilakukan sejak sebelum memasuki lapangan, selama di lapangan dan selesai di lapangan.

\section{HASIL PENELITIAN DAN PEMBAHASAN}

Potensi pertanian yang dimiliki oleh Kabupaten Boalemo khususnya Kecamatan Paguyaman saat ini sudah sangat besar dan berkembang dengan pesat. Hal ini dapat dibuktikan dengan adanya beberapa usaha dari masyarakat untuk memanfaatkan lahan yang ada untuk ditanami berbagai jenis komoditi tanaman pertanian, salah satunya adalah tanaman kakao.

Desa Balate merupakan salah satu desa yang terdapat di Kecamatan Paguyaman yang telah berhasil mengembangkan komoditi tanaman kakao. Potensi pertanian yang ada di desa ini terdiri dari budi daya komoditi tanaman kakao, jagungdan kacang. Selain potensi komoditi pertanian yang ada, Desa Balate juga memiliki keindahan panorama pegunungan yang dapat menjadi daya tarik bagi orang yang datang berkunjung di desa ini. Dengan demikian Desa Balate sebagai desa yang dikenal dalam mengembangkan komoditi kakao ini memiliki potensi untuk dikembangkan sebagai destinasi agrowisata.

Sutjipta (2001) mendefinisikan, agrowisata adalah sebuah sistem kegiatan yang terpadu dan terkoordinasi untuk pengembangan pariwisata sekaligus pertanian, dalam kaitannya dengan pelestarian lingkungan, peningkatan kesajahteraan masyarakat petani.

182 AKSARA Jurnal Ilmu Pendidikan Nonformal 


$\begin{array}{ll}\text { Volume } & : 05 \\ \text { Nomor } & : 03 \\ \text { Bulan } & : \text { September } \\ \text { Tahun } & : 2019 \\ \text { http } & : \text { //ejurnal.pps.ung.ac.id/index.php/AKSARA/index }\end{array}$

Beeton (2006) dalam Aref dan Gill (2009) menyatakan bahwa agrowisata (agrotourism) merupakan salah satu istilah yang digunakan untuk mendeskripsikan wisata di pedesaan (rural tourism), selain farm tourism, soft tourism dan ecotourism. Hal ini mengacu pada definisi yang diberikan dalam Knowd (2001) tentang rural tourism yang memposisikan pertanian dan lahannya sebagai fondasi atau dasar semua daya tarik yang dibangun di atasnya. Pemerintah melalui Surat Keputusan Bersama Menparpostel dan Menteri Pertanian No. KM.47/PW.004/MPPT/89 dan No. 204/KPTS/HK050/4/1989, mendefinisikan "Agrowisata adalah suatu kegiatan pariwisata yang memanfaatkan usaha agro sebagai obyek wisata untuk memperluas pengetahuan, pengalaman rekreasi dan hubungan usaha dibidang agro".

Pada pengembangan agrowisata di suatu kawasan lahan pertanian perlu memperhatikan beberapa aspek atau syarat-syarat yang berhubungan dengan pengembangan wisata agro tersebut.

Menurut Widji (2010) pada penelitian tentang "Perencanaan Pengembangan Kawasan Agrowisata" dalam perencanaan agrowisata ada beberapa hal yang menjadi syarat yang perlu diperhatikan oleh pihak yang ingin mengelola suatu kawasan agrowisata, antara lain :

1. Memiliki sumberdaya lahan dengan agroklimat yang sesuai untuk mengembangkan komoditi pertanian yang akan dijadikan komoditi unggulan.

Berdasarkan hasil penelitian dilapangan bahwa Desa Balate telah memiliki komoditi tanaman pertanian seperti komoditi tanaman kakao, jagung dan kacang yang sudah dikembangan sesuai iklim desa tersebut. Komoditi tanaman kakao dapat dijadikan sebagai komoditi unggulan dalam wisata agro di desa ini.

2. Memiliki prasarana dan infrastruktur yang memadai untuk mendukung pengembangan sistem dan usaha agrowisata, seperti misalnya: jalan, sarana irigasi/pengairan, sumber air baku, pasar, terminal, jaringan telekomunikasi, fasilitas perbankan, pusat informasi pengembangan agribisnis, sarana produksi pengolahan hasil pertanian, dan fasilitas umum serta fasilitas sosial lainnya.

Pada saat dilakukan penelitian Desa Balate memiliki kondisi akses jalan yang cukup baik dengan lebar jalan $\pm 3 \mathrm{~m}$, sumber air bersih yang cukup memadai, moda transportasi yang cukup memadai, dan jaringan telekomunikasi yang cukup memadai. Namun desa ini belum memiliki fasilitas untuk menunjang kegiatan pariwisata khususnya agrowisata seperti akomodasi, restoran, pusat informasi wisata, dan souvenir shop.

3. Memiliki sumberdaya manusia (SDM) yang berkemauan dan berpotensi untuk mengembangkan kawasan agrowisata.

Berdasarkan hasil wawancara dengan masyarakat Desa Balate dalam hal ini kelompok petani kakao yang diketuai oleh Bapak Sugianto Lauped, menyatakan bahwa petani dikelompok tani ini sangat setuju apabila lahan pertanian mereka dijadikan sebagai destinasi agrowisata. Hal ini dikarenakan setelah adanya penjelasan tentang dampak positif yang diterima oleh petanipetani strroberi di Ciwidey Kabupaten Bandung yang telah mengembangkan agrowisata strowberi dengan baik.

Untuk mengetahui lebih jelasnya respon masyarakat terhadap pengembangan agrowisata di desa Balate dapat dilihat pada tabel berikut:

Tabel 1 Pendapat Masyarakat khususnya Kelompok Tani Tanaman KakakoXTentang Perencanaan Agrowisata di Desa Balate 


$$
\begin{array}{ll}
\text { Volume } & : 05 \\
\text { Nomor } & : 03 \\
\text { Bulan } & : \text { September } \\
\text { Tahun } & : 2019 \\
\text { http } & : / / \text { ejurnal.pps.ung.ac.id/index.php/AKSARA/index }
\end{array}
$$

\begin{tabular}{|l|l|l|l|}
\hline No. & $\begin{array}{l}\text { Pendapat } \\
\text { Masyarakat }\end{array}$ & Jumlah & Presentase \\
\hline 1. & Sangat Setuju & 15 & $41 \%$ \\
\hline 2. & Setuju & 22 & $59 \%$ \\
\hline 3. & Sangat Tidak Setuju & - & - \\
\hline 4. & Tidak Setuju & - & - \\
\hline Jumlah & $\mathbf{3 7}$ & $\mathbf{1 0 0 \%}$ \\
\hline
\end{tabular}

Sumber Data: Hasil wawancara dengan kelompok tani kakao 26 Juni2013

Dari tabel pendapat masyarakat khususnya kelompok petani tanaman kakao di Desa Balate, dapat dilihat $15 \mathrm{responden/masyarakat} \mathrm{(41 \% )} \mathrm{mengatakan} \mathrm{sangat} \mathrm{setuju} \mathrm{tentang} \mathrm{adanya}$ pengembangan agrowisata di Desa Balate, dan 22 responden (59\%) setuju adanya pengembangan agrowisata ini. Dengan demikian, adanya perencanaan pengembangan agrowisata di desa Balate mendapat resepon yang baik dari masyarakat khususnya petani kakao dan aparatur Desa Balate. Hal ini disebabkan masyarakat sadar akan potensi yang dimiliki oleh Desa Balate dalam menuju pengembangan agrowisata. Menurut penjelasan ketua kelompok tani budi daya tanaman kakao Bapak Sugianto Lauped, mengatakan "saya sebagai ketua kelompok tani mewakili kelompok tani kami, sangat menyambut baik perencanaan pengembangan agrowisata di desa ini terutama pada lahan pertanian kami karena dengan begitu dapat membantu petani untuk mempermudah menjual hasil panen kakao kami". Sedangkan pegawai pemerintah desa dalam hal ini Kepala desa menyatakan "kami sangat mendukung adanya program agrowisata di desa ini karena dengan begitu dapat memberi alternatif pekerjaan lain kepada petani sekaligus dapat memperkenalkan tanaman kakao desa ini pada masyarakat luas". (Hasil wawancara dengan masyarakat petani kakao pada tanggal 26 Juni 2013).

Untuk mengetahui lebih jelasn tentang pendapatan masyarakat di Desa Balate dari hasil panen kakao setiap panen dapat dilihat pada tabel berikut ini:

Tabel 2 Hasil Pendapatan Tanaman Kakao

\begin{tabular}{|l|l|l|l|}
\hline No. & Jumlah Pendapatan & Jumlah Orang & Presentase \\
\hline 1. & $500.000-1.000 .000$ & 9 & $24 \%$ \\
\hline 2. & $1.500 .000-2.000 .000$ & 23 & $62 \%$ \\
\hline 3. & $2.500 .000-3.000 .000$ & 5 & $14 \%$ \\
\hline Total & $\mathbf{3 7}$ & $\mathbf{1 0 0} \%$ \\
\hline
\end{tabular}

Sumber Data: Hasil wawancara dengan kelompok tani kakao 26 Juni2013

Berdasarkan tabel hasil pendapatan tanaman kakao diatas, maka dapat dilihat bahwa sebagian besar masyarakat yang ada pada kelompok tani kakao yang di ketuai oleh Bapak Sugianto Lauped, pendapatan berasal dari hasil bumi tanaman kakao (buah kakao). Dimana pendapatan yang diperoleh dari hasil panen tanaman kakao setiap panen dengan jumlah pendapatan sekitar Rp. 500.000 sampai Rp. 1.000.000 sebesar 24\%, Rp. 1.500.000 sampai dengan 2.000.000 sebesar 62 $\%$ dan sisanya $14 \%$ dengan jumlah pendapatan 2.500.000 sampai dengan 3.000.000. Hasil panen yang berbeda-beda ini disebabkan oleh adanya hasil panen yang rusak saat panen dilakukan. Hasil buah kakao yang rusak ini karena adanya hama penyakit yang datang saat waktu panen mulai tiba.

Potensi yang dimiliki oleh Desa Balate berupa komoditi tanaman pertanian kakao, jagung dan kacang belum menjadi aspek utama dalam menetukan desa ini berpotensi dan layak dijadikan 


$\begin{array}{ll}\text { Volume } & : 05 \\ \text { Nomor } & : 03 \\ \text { Bulan } & : \text { September } \\ \text { Tahun } & : 2019 \\ \text { http } & : \text { //ejurnal.pps.ung.ac.id/index.php/AKSARA/index }\end{array}$

sebagai agrowisata di Kabupaten Boalemo. Oleh karena itu diperlukan suatu kegiatan identifikasi potensi studi kelayakan pariwisata.

Menurut Janianton Damanik \& Helmut F. Weber (2006:52) Studi kelayakan potensi pariwisata (feasibility study) merupakan kajian yang bersifat praktis atas berbagai keunggulan dan kelemahan sumberdaya yang tersedia, yang akan dijadikan basis penyusunan rencana proyek.

\section{PENUTUP}

Setelah dilakukan bahasan dan hasil penelitian dapat disimpulkan bahwa: Desa Balate memiliki potensi sumberdaya alam pertanian dengan beberapa komoditi tanaman pertanian yang telah dikembangkan sejak dulu. Selain itu desa ini juga memiliki panorama pegunungan yang indah. Sehingga dapat berpotensi dikembangkan sebagai agrowisata di Kabupaten Boalemo.

Aktivitas wisata yang menjadi daya tarik utama seperti wisata edukasi yakni dalam hal ini mempelajari tentang tanaman pertanian komoditi kakao, pengalaman dalam memetik hasil buah tanaman pertanian yang ada, pengetahuan tentang menanam bibit tanaman pertanian kakao dan membeli hasil atau buah tanaman kakao.

Alternatif aktivitas wisata yang dapat dilakukan adalah rekreasi seperti fotografi, jalan-jalan mengelilingi lahan pertanian dan outbound.

\section{DAFTAR PUSTAKA}

Aby Legawa, 2008, “Manajemen-Destinasi-Pariwisata” (Di akses jam 20.00 pada tanggal 4 Juni 2013). abylegawa.blogspot.com/2008/11/manajemen-destinasipariwisata.html

Depnarketrans, 2012. "Selayang Pandang Kabupaten Boalemo KTM Pawonsari” (Di akses jam 19.00 pada tanggal 19 Maret 2013). http://id. depnarketrans /selayang_pandang_kabupaten_boalemo.

Deptan, 2005. “Agrowisata Meningkatkan Pendapatan Petani” Di akses (Jam 20:00, pada 19 Maret 2013). http://database.deptan.go.id

Inskeep Edward, Tourism Planning an Integrated and Sustainable and Sustainable Development Approuch, United State Of America, Library Congress Cataloging-in-publication Data, 1991,

Hidayat Salim, Pengantar Ilmu Pertanian, Yogyakarta, Graha Ilmu, 2012.

Danamik Janianton \& Helmut F. Weber, "Perencanaan Ekowisata ; Dari Teori Ke Aplikasi, Yogyakarta,Pusat Studi Pariwisata UGM, 2006.

Muljadi A.J, Kepariwisataan dan Perjalanan, PT. RajaGrafindo Persada, Jakarta 2009.

Norton Agusmanto, 2012, “Analisis Potensi Agrowisata Disekitar Lokasi Danau 


$\begin{array}{ll}\text { Volume } & : 05 \\ \text { Nomor } & : 03 \\ \text { Bulan } & : \text { September } \\ \text { Tahun } & : 2019 \\ \text { http } & : / / \text { ejurnal.pps.ung.ac.id/index.php/AKSARA/index }\end{array}$

PLTA Di Kecamatan XIII Koto Kampar Kabupaten Kampar" (Di akses jam 09.10 pada tanggal 1 Mei 2013). http://eprints.undip.ac.id/15372/1/Norton Agusmanto.pdf

Robby K.T.Ko, 2001, “Pedoman Identifikasi, Pengembangan, Pengelolaan,

Pemeliharaan, Pemasaran Obyek Wisata Alam, Yayasan Buena Vista, Cisarua Bogor.

Widji, 2010. "Perencanaan Pengembangan Wisata Agro" Di akses jam 09.00 pada 1

Mei 2013). http://joecky.wordpress.com/2010/03/29/perencanaan-pengembangan-

kawasan-agrowisata

186 AKSARA Jurnal Ilmu Pendidikan Nonformal 